\title{
Light and electron microscopy study of late embryonic development in the land snail Limicolaria flammea (Müller) (Pulmonata, Achatinidae)
}

\author{
Rosemary I. Egonmwan
}

Department of Zoology, University of Lagos. Akoka, Lagos, Nigeria. E-mail: egonmwanr@yahoo.com

\begin{abstract}
The late stages of embryogenesis in the achatinid land snail Limicolaria flammea (Müller, 1774) were described using light and electron microscopy. Embryos at various stages of development were present in the eggs during the first hour after they were laid, from 4-cell blastulae to morulae and fairly advanced stages. The advanced embryo which was fully developed on the second day bears a long cephalic sac, first to be developed, attached to the embryo and a podocyst which is attached to the foot of the embryo. Both of these structures are reduced in size as embryogenesis progresses until they finally disappear at about the $7^{\text {th }}$ day after the egg was deposited. The embryonic shell was apparent on the second day and spiral coiling was apparent at about day 5. The spiral shell had one whorl when formed and more spirals were added so that at hatching the young snails had three whorls.

KEY WORDS. Cephalic sac; embryo; embryonic shell; foot; podocyst.
\end{abstract}

RESUMO. Microscopias óptica e eletrônica dos estágios embrionários do caracol Limicolaria flammea (Müller) (Pulmonata, Achatinidae). Os estágios finais da embriogênese do caracol Limicolaria flammea (Müller, 1774) foram descritos por meio de observações a partir de microscopia óptica e eletrônica. Embriões em vários estágios de desenvolvimento estavam presentes em ovos durante a primeira hora ou logo após a desova, de blástulas tetra celulares a mórulas e estágios avançados. Embriões avançados, totalmente desenvolvidos no segundo dia, apresentaram uma longa base cefálica, a primeira a desenvolver-se, aderida ao embrião e um podocisto aderido ao pé do embrião. Ambas estruturas reduziram de tamanho à medida que a embriogênese progrediu, até finalmente desaparecer próximo do sétimo dia após a oviposição. A concha embriogênica foi evidenciada no segundo dia e o enrolamento espiral foi aparente próximo ao quinto. A concha espiralada possuia uma volta quando formada e mais espirais foram adicionadas e assim, quando da eclosão, o jovem tinha três voltas.

PLAVRAS-CHAVE. Bolsa cefálica; concha embrionária; embrião; pé; podocisto.

Limicolaria flammea (Müller, 1774), belonging to family Achatinidae, is widely distributed in West Africa, from Ghana to Angola (Crowley \& Pain 1970). The species is used as a protein source in many West African countries including Nigeria (Bequaert 1950). Despite the economic importance of these snails as food, there are very few published studies on their biology (Egonmwan 1990) and little is known about the development of the embryo except for the description of embryonic development of the giant snail Archachatina marginata (Swainson, 1821) by BRISSON $(1964,1968)$.

One advantage that an internally fertilized egg has is that the egg can be provided with nutritive yolk as well as with protective egg shells or egg capsules which ensures the greater safety of the offspring. Most molluscs are known to secrete external calcareous shells which begin during early embryogenesis (TAKAICHI et al. 2003). Molluscan eggs vary from simple zygotes with only primary or vitelline membrane to large ones, with several protective membranes and a nutrient store which in terrestrial gastropods allow the provision of a specialized environment for the development of the embryo which consumes a different food resource to the adults (RunHAm 1994). The eggs of L. flammea have hard calcareous shells and each egg constitutes $0.65 \%$ of the body weight of the adult snail (EGONMWAN 2004). Large eggs have large nutritive stores within the zygote and are packed in a variety of nutritive and protective layers (Runham 1994). The shell which develops partially during embryonic development of the snail is called a protoconch; before torsion the protoconch is composed of flexible organic material (ColuIN \& Voltzow 1998) which can be easily deformed asymmetrically by the pressure from the foot and contraction of the larval retractile muscles resulting in coiling of the formerly symmetrical embryonic shell. An organic layer is deposited in the shell of gastropods before calcification begins (Collin \& Voltzow 1998) and measurable calcium levels was reported in the protoconch of pulmonate embryos, which was obtained from the egg shell calcium (ToMPA 1975). Sibling 
neonates get a faster start in growth by eating their egg shells and the egg shells and albumen of unhatched dead eggs in the nest (Tompa 1984, Baur \& Baur 1986, Baur 1990, Desbuquois 1997, Desbuquois \& MADEC 1998).

Stylommatophora exhibits intracapsular direct development (BARKER 2001), characterized by the absence of a velum (JeRUSALIMSKY \& BALABAN 2001), therefore the term veliger cannot be used to describe their larvae. Instead like in Helix aspersa Müller, 1774, the larva develops a cephalic vesicle and a pedal sinus (Jerusalimsky \& BaLaban 2001) or cephalic sac and podocyst (Brisson 1964, Cather \& TOMPa 1972, KuChenmeister et al. 1996) which are advancements over other pulmonates.

This paper describes the general features of the embryonic stages of late ontogeny of Limicolaria flammea (Müller).

\section{MATERIAL AND METHODS}

The eggs were obtained from $L$. flammea reared in the laboratory from hatching. The eggs were collected on the day they were laid, usually in the morning after carefully searching the soil and under leaves in the rearing pen. The eggs were carefully cleaned of adhering soil, measured and were placed on top of moist tissue papers in a small bowl with a lid and then covered with another layer of moist tissue paper. The bowl was placed in an incubation chamber maintained at $25^{\circ} \mathrm{C}$. Embryos were observed periodically every five hours and were photographed to illustrate sequential stages of development.

Each egg was opened under a stereo zoom microscope with fine needles in $0.7 \%$ sodium chloride solution. The embryos were examined alive under a dissecting microscope and fixed for light and electron microscopy. The embryos were fixed in buffered formol-saline for three days and rinsed with saline and distilled water before they were stained in Mayer's carmalum for 20 minutes. Excess stain was removed with acid alcohol, the embryos were dehydrated through graded ethanol and whole mount slides were made.

The surface of the embryo was studied by scanning electron microscope (SEM). The eggs were opened under a stereo zoom microscope and the embryos placed on clean cover-slips which were immersed in $2.5 \%$ glutaraldehyde fixative in $0.1 \mathrm{M}$ sodium cacodylate buffer ( $\mathrm{pH}$ 7.4) to fix the embryos. After fixation the embryos were rinsed in the cacodylate buffer and dehydrated through graded series of ethanol and acetone and later critical point dried and coated with gold. The embryos were observed in a Philips 515 scanning electron microscope.

\section{RESULTS}

\section{The egg}

Limicolaria flammea produced between 1 and 56 eggs nearly all year round in the laboratory. The eggs which are coated with a thin layer of mucus are lemon yellow in colour and sometimes whiten with age. The eggs are ellipsoidal in shape and weighed between $20-40 \mathrm{mg}($ mean $=30.0 \pm 2.0, \mathrm{n}=27)$ and measured between 3.5-4.5 $\mathrm{mm}$ in length and 3.2-3.9 $\mathrm{mm}$ in diameter.

\section{Light microscope observations}

Table I shows the sequence of developmental stages of $L$. flammea eggs using light microscope. Embryo at various stages of development were present in the eggs during the first hour or so after they are laid, from 4-cell blastulae to morulae and fairly advanced stages. At 6-20 hours after deposition of a fertilized egg the embryo is at morula stage. At 24 hours, the embryo is at late gastrula stage and at 30 hours it is at cephalic sac stage (Figs 1 and 2).

Table I. Time of developmental stages in L. flammea. The eggs were incubated at $25^{\circ} \mathrm{C}$ in an incubation chamber ( $n=15$ clutches).

\begin{tabular}{cl}
\hline Time after egg deposition & \multicolumn{1}{c}{ Characteristics } \\
\hline 1 to 10 hours & Blastula/morula stage \\
24 hours & Late gastrula stage \\
30 hours & Cephalic sac stage \\
3 days & Pre -torsional stage \\
5 days & Post torsional stage \\
7 days & Spiral shell fully developed \\
\hline
\end{tabular}

\section{4-36 hours old embryo}

The embryo which is pre-torsional measures about $0.4 \mathrm{~mm}$ in length and $0.54 \mathrm{~mm}$ in width. The cephalic sac which is very prominent at this stage measures $1.40-1.84 \mathrm{~mm}$. The podocyst is small and measures about $0.6-0.7 \mathrm{~mm}$ in length. In a 24 hour old embryo (Fig. 1), the embryonic shell is not very visible but in a 36 hour embryo (Fig. 2) the embryo is covered by a small embryonic shell inside which is the visceral mass (Fig. 2). The embryonic shell or protoconch is a rounded structure and fits like a cap to the embryo body. The cephalic sac is a pulsating structure attached to the embryo near the foot (Figs 1 and 2). The podocyst is a sac-like structure attached to the foot (Figs 1 and 2) and rest on the shell and it is apparent after the formation of the cephalic sac.

\section{Three days old embryo}

At this pre-torsional age (Fig. 3) the embryo measures $1.5 \mathrm{~mm}$ in length and $1.4 \mathrm{~mm}$ in width. Both the cephalic sac and podocyst are very prominent. The embryonic shell is still rounded and cap like but now expanded and very visible.

\section{Five days old embryo}

Torsion has taken place and the embryonic shell is prominent (Fig. 4) and appears thickened. Cephalic sac and podocyst are gradually disappearing and by $7^{\text {th }}$ day both of these two structures had disappeared. The embryonic shell or protoconch which is apparent at about day 2 becomes spirally coiled on day 5 (Fig. 4). The embryo has one whorl of spirally coiled shell and resembles a small snail.

\section{Scanning electron microscope observation}

At two days old the shell has been formed (Fig. 5) and the embryonic foot is also formed. At two to three days old

Revista Brasileira de Zoologia 24 (2): 436-441, junho 2007 

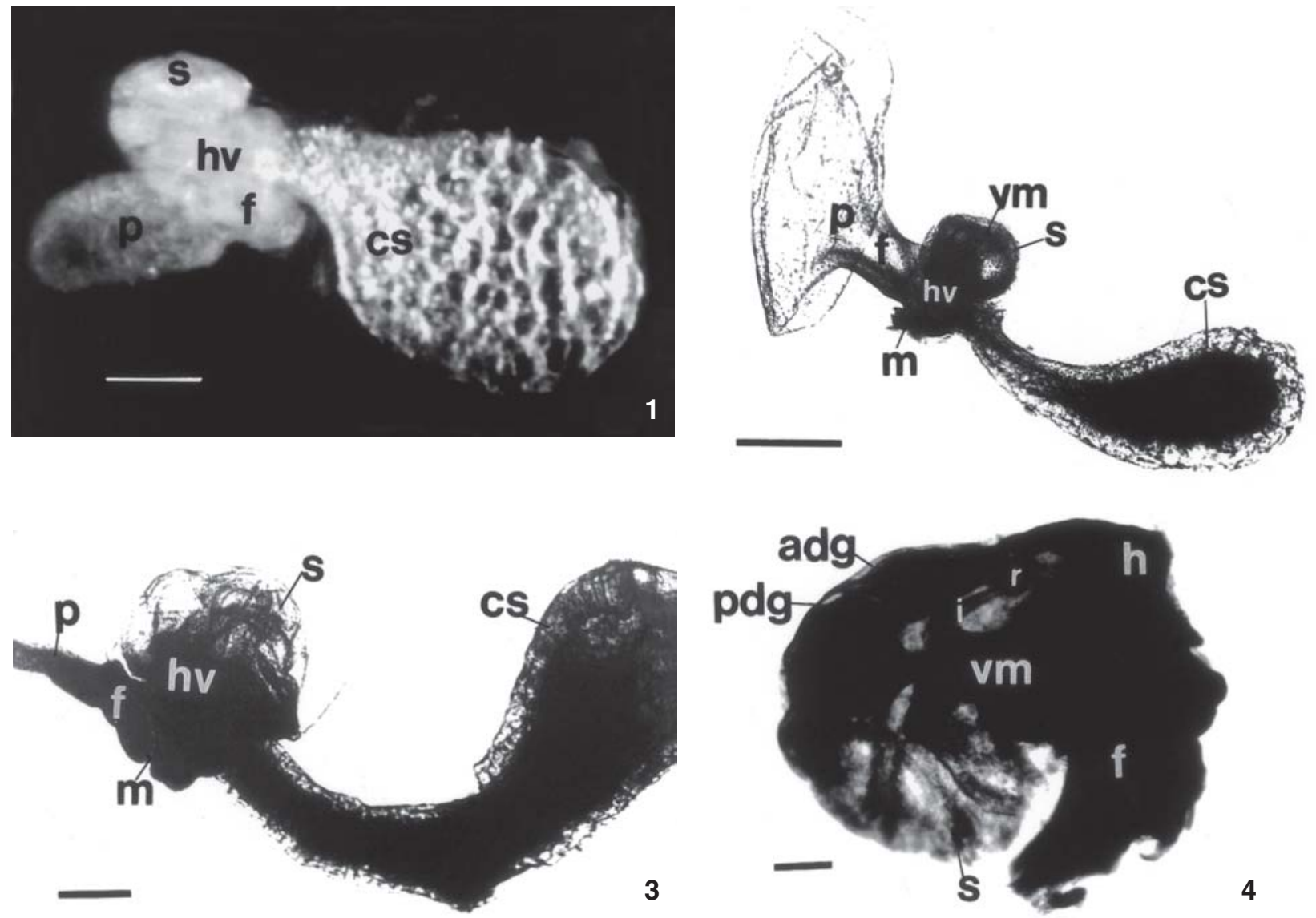

Figures 1-4. Embryonic stages of Limicolaria flammea, seen with light microscope: (1) $24 \mathrm{~h}$ old embryo: note the enlarged cephalic sac and short podocyst; (2) $36 \mathrm{~h}$ old embryo: note enlarge cephalic sac and podocyst; (3) three days old embryo; (4) five days old embryo: note spiral coiling of the shell and absence of podocyst and cephalic sac. (cs) Cephalic sac, (f) foot, (h) head, (hv) head vesicle-visceral mass, (i) intestine, $(\mathrm{m})$ mouth, $(\mathrm{p})$ podocyst, (pdg) posterior digestive gland, (r) rectum, (s) shell, (vm) visceral mass. Scale bar: (1) 250 $\mu \mathrm{m},(2-3) 500 \mu \mathrm{m},(4) 250 \mu \mathrm{m}$.

(Fig. 6), the shell is fully formed thickened and does not show any sculpturing. At three to four days (Fig. 7), the podocyst is very visible. At five days, the shell of the post torsional embryo shows sculpturing, is spirally coiled (Fig. 8) and has one whorl.

\section{Hatching}

More spirals coils are added to the shell so that at hatching the young snails has two to three whorls. The period between the time the clutch is laid and when the eggs hatch in $L$. flammea varies between 14 and 28 days ( $21.0 \pm 0.6$ days, $\mathrm{n}=24)$.

\section{DISCUSSION}

A five stage scale of late embryonic development was established for Limicolaria flammea based on comparison with the embryonic stages described for other Achatinidae (BRISSON 1964, 1968) and other Stylommatophora (CATHER \& TOMPA 1972, KuCHENMEISTER et al. 1996).

Revista Brasileira de Zoologia 24 (2): 436-441, junho 2007
In $L$. flammea, the embryonic development at $25^{\circ} \mathrm{C}$ extends over a period of 14 to 28 days. Although clutches of the same egg clearly do not necessarily have embryos at the same stage of development, no eggs were observed to contain almost mature juveniles that hatched after 24 to 36 hours, as has been observed in Achatina fulica (Ferussac, 1821) (Ghose 1960, PAWSON \& CHASE 1984) and Limicolaria martensiana (Smith, 1880) (OWEN 1965, OwINy 1974). In L. martensiana eggs require 13 to 23 days to hatch in the rainy season but during the dry season, the eggs are retained in utero where they hatch when the snail aestivates and the young are deposited during the dry season. Limicolaria martensiana is therefore oviparous during the rainy season and ovoviviparous during the dry season (OwINY 1974). Ovoviviparity was not observed in L. flammea during this study, probably due to the fact that the snails used for this study were reared from hatching in a constant environment permanently kept moist. 

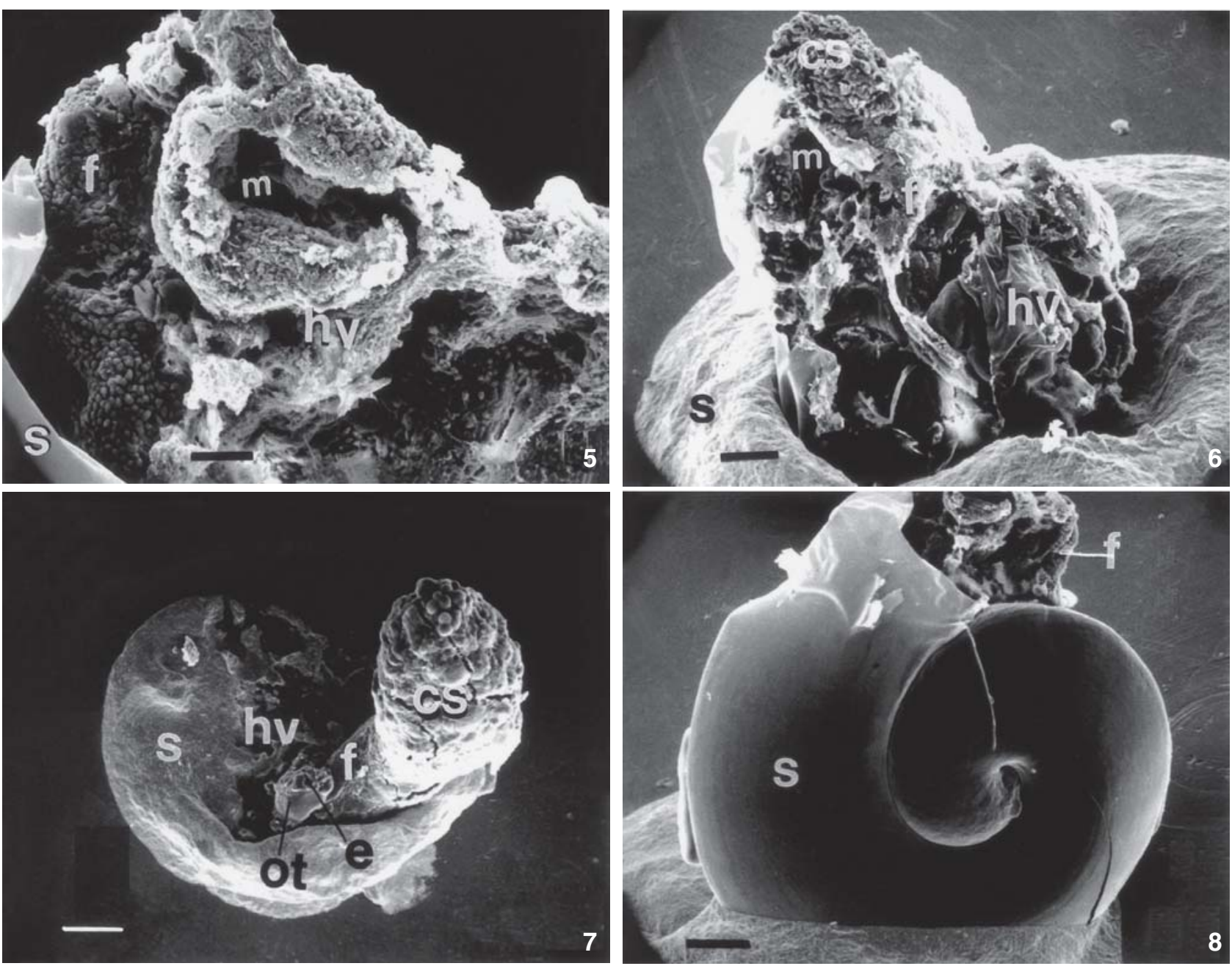

Figures 5-8. Embryonic stages in Limicolaria flammea, seen with SEM: (5) two days old embryo; (6) two-three days old embryo; (7) threefour days old embryo: note the cephalic sac; (8) five days old embryo: note spiral coiling of the shell. (cs) Cephalic sac, (e) eye rudiment, (f) foot, (hv) head vesicle-visceral mass, (m) mouth, (ot) ocular tentacle, (s) shell. Scale bar: (5) $50 \mu \mathrm{m},(6) 100 \mu \mathrm{m},(7-8) 200 \mu \mathrm{m}$.

The observations of the embryo in the present study are consistent with the observations on the development of Limax maximus Linnaeus, 1758 (Kuchenmeister et al. 1996) and Archachatina marginata (BRIsson 1964, 1968). The cephalic sac is the first to be formed in the embryo of $L$. flammea followed by the podocyst. The cephalic vesicle which is superficially similar to the cephalic mass of some prosobranch (JeRUSALIMSKY \& BaLABan 2001) represents a modified velum that circulates the body fluid through the haemocoel and disappears two days prior to hatching in Helix aspersa (JerusaLIMSKY \& BaLABAN 2001). The development of the cephalic sac, podocyst and heart is temperature dependent (KuChenmeister et al. 1996). The cephalic sac was absent in all specimens of $L$. flammea examined at hatching.

The podocyst which has been described as a giant thin walled pulsatile sac is attached to the foot of the embryo (CATHER $\&$ Tompa 1972) or an extension of the embryonic foot (TомPA 1984) in Strophocheilus oblongus. It has also been described as a pedal sinus in $H$. aspersa by JERUSALIMSKY \& BALABAN (2001). While a circulatory and respiratory functions have been attributed to it by (KuCHENMEISTER et al. 1996), resorption of albumen and calcium from the egg shell (Сатнев \& TOMPA 1972, TомРA 1984). JERUSALIMSKY \& BALABAN (2001) are of the opinion that the pedal sinus elongates the foot and participates both in the embryo movements and respiration, so is probably analogous to the avian chorioallantois in dissolving the shell for its calcium needs (Tompa 1984). In the slug Limax maximus, the cephalic sac and podocyst develop earlier than the heart whose activity is continuous with that of the cephalic sac and podocyst in the early embryo (KuChenmeister et al. 1996) and both contract indepen-

Revista Brasileira de Zoologia 24 (2): 436-441, junho 2007 
dently. The exact time when torsion occurred was not observed during this study, however by the 4th day, the embryos were showing evidence of torsion.

The production of an embryonic shell, the protoconch, in L. flammea embryo is consistent with the short embryonic development (BARKER 2001). The embryonic shell in L. flammea has one whorl when formed and at hatching it is increased to 2 to 3 shell whorls, consistent with other stylommatophorans. The shell gland in Achatina fulica develops by the thickening of the ectodermal layer of the postero-dorsal part of the embryo (GHOSE 1962), although the exact time during development when the first shell material is secreted in molluscs varies among species (Eyster \& Morse 1984). In L. flammea, the protoconch is visible in 2 days old embryo and like the shells of the adult the embryonic shell consists of both organic component and inorganic components. The organic material is secreted first and serves as a matrix upon which the calcareous shell material nucleates (EYSTER \& MORSE 1984) which is not supplied from external source (TAKAICHI et al. 2003). In addition to mechanical support, the function of the calcified egg shell is to supply the developing embryo with calcium to form the embryonic shell by the time of hatching (TомPA 1979a, b, 1980, 1984). Coiling was observed in late post torsional shell in L. flammea similar to that reported in archaeogastropods probably due to growth around the aperture and thickened lips (ColuIN \& Voltzow 1998). Embryos need more calcium than can be provided in the egg albumen and many terrestrial snails are known to cover their terrestrial eggs with soil rich in calcium (Tомpa 1980).

\section{REFERENCES}

BARKER, G.M. 2001.Gastropods on land: phylogeny, diversity and adaptive morphology, p. 1-146. In: G.M. BARKER (Ed). The Biology of Terrestrial Molluscs. Oxford, CABI Publishing.

BAUR, B. 1990. Possible benefits of egg cannibalism in hatchlings of the land snail Arianta arbustorum L. Functional Ecology 4: 679-684.

BaUR, B. \& A. BAUR. 1986. Proximate factors influencing egg cannibalism in the land snail Arianta arbustorum (Pulmonata, Helicidae). Oecologia 70: 283-287.

Bequaert, J.C. 1950. Studies in the Achatininae, a group of African land snails. Bulletin of the Museum of Comparative Zoölogy 105: 1-216.

BRISSON, P. 1964. Annexes embryonnaires chez Archachatina (Calachatina) marginata (Swainson) Mollusque Gastéropode Pulmoné).Comptes rendus de l'Academie des sciences 259: 3620-3623.

Brisson, P. 1968. Développment de l'embryon et de ses annexes et étude en culture in vitro chez les achatines (Gasteropodes puslmonés). Archives d'Anatomie Microscopique et de Morphologie 57 (4): 345-368.

Cather, J.N. \& A.S. Tompa. 1972. The podocyst in pulmonate evolution. Malacological Review 5: 1-3.

Collin, R. \& J. Voltzow. 1998. Initiation, calcification and form of larval archaeogastropod shells. Journal of Morphology 235: 77-89.

CRowley, T.E. \& T. PAIN. 1970. A monographic revision of the African land snails of the genus Limicolaria Schumacher (Mollusca Achatinidae). Musée Royale de l'Afrique Centrale, Tervuren, Belgique annales, Série In-8, Sciences Zoologiques 177: 161.

DesBuquors, C. 1997. The influence of egg cannibalism on growth, survival and feeding in hatchlings of the land snail Helix aspersa Müller (Gastropoda: Pulmonata: Stylommatophora). Reproduction, Nutrition and Development 37: 191-202.

Desbuquois, C. \& L. Madec. 1998. Within-clutch egg cannibalism variability in hatchlings of the land snail Helix aspersa (Pulmonata: Stylommatophora): influence of two proximate factors. Malacologia 39 (1-2): 167-173.

EgONMWAN, R.I. 1990. Reproduction in the garden snail Limicolaria flammea (Gastropoda: Pulmonata: Achatinidae). Bioscience Research Communications 2: 139-152.

EGONMWAN, R.I. 2004. Maturation timing in the land snails Archachatina marginata ovum (Pfeiffer) and Limicolaria flammea (Müller). Invertebrate Reproduction and Development 46 (2-3): 159-172.

Eyster, L. \& M.P. Morse. 1984. Early shell formation during Molluscan Embryogenesis, with New Studies on the Surf Clam, Spisula solidissima. American Zoologist 24: 871-882.

GHose, K. C. 1960. Observations on the gametes, fertilisation and gonadal activities of two land Pulmonata Achatina fulica Bowdich and Macrochlamys indica Godwin-Austen. Proceedings of the Zoological Society 13: 91-96.

GHose, K. C. 1962. Morphogenesis of the shell gland, lung, mantle and mantle cavity of the giant land snail, Achatina fulica. Proceedings of the Malacological Society 35: 119-126.

Jerusalimsky, V.N. \& P.M. Balaban. 2001. Ontogenesis of the snail Helix aspersa: Embryogenesis timetable and ontogenesis of GABA-like immunoreactive neurons in the central nervous system. Journal of Neurocytology 30: 73-91.

Kuchenmeister, G.M.; D.J. Prior \& I.G. Weisford. 1996. Quantification of the development of the cephalic sac and podocyst in the terrestrial gastropod Limax maximus $\mathrm{L}$. Malacologia 38 (1-2): 153-160.

OwEN, D.F. 1965. A population study of an equatorial land snail, Limicolaria martensiana. Proceedings of the Zoological Society 144: 361-382.

OWINY, A.M. 1974. Some aspects of the breeding biology of the equatorial land snail Limicolaria martensiana (Achatinidae: Pulmonata). Journal of Zoology 172: 191-206.

PAwson, P.A. \& R. Chase. 1984. The life cycle and reproductive activity of Achatina fulica (Bowdich) in laboratory culture. Journal of Molluscan Studies 50: 85-91.

RunHam, N.W. 1994. Asexual propagation and reproductive strategies: 11. Mollusca, p. 310-383. In: K.G. ADIYODI \& R.G. ADIYODI (Eds). Reproductive biology of invertebrates. Wiley, Chichester, vol. 6. 
Takaichi, S.; V. Mizuhira; H. Hasegawa.; T. Suzaki; M. Notoya; S. EjIRI; H. OzaWA \& J.H. vaN WYK. 2003. Ultrastructure and early embryonic shell formation in the terrestrial pulmonate snail, Euhadra hickornis. Journal of Molluscan Studies 69: 229-244.

Tompa, A.S. 1975. Embryonic use of egg shell in a gastropod. Nature 255: 232-233.

TOMPA, A.S. 1979a. Localized egg shell dissolution during development in Stenotrema leai (Pulmonata: Polygyridae). Nautilus 94 (4): 136-137.
TomPA, A.S. 1979b. Oviparity, egg retention and ovoviviparity in pulmonates. Journal of Molluscan Studies 45: 155-160.

TompA, A.S. 1980. Studies of the reproductive biology of gastropods: 111.Calcium provision and the evolution of terrestrial eggs among gastropods. Journal of Conchology 30: 145-154.

TompA, A.S. 1984. Land snails (Stylommatophora), p. 47-140. In: K.M. Wilbur (Ed). The Mollusca. New York, vol. 7, Academic Press, 486p.

Received in 21.VI.2006; accepted in 17.V.2007. 